\author{
Ганна Зіновї̈вна Огнев'юк, \\ кандидат юридичних наук, доиент кафедри \\ інтелектуальної власності Київського національного \\ університету імені Тараса Шевченка
}

\title{
ДІЯ ЗАКОНУ У ЧАСІ ЯК ВИМОГА ПРАВОВОЇ ВИЗНАЧЕНОСТІ
}

Постановка проблеми. Дія закону у часі $є$ одним з важливих правових питань, яке пов'язане з практичним втіленням правових приписів безпосередньо у керівні положення для суб'єктів правовідносин. Темпоральна дія закону набуває особливої гостроти і актуальності у період кардинальних змін у законодавстві, тоді, коли підходи до правового регулювання відносин змінюються, виникає ситуація, за якої те, що ще вчора вважалось правомірним, сьогодні опиняється поза законом і навпаки. Такі зміни створюють ситуацію невизначеності для учасників відносин, вимагають від них швидкої адаптації до існуючих змін. Тому зв'язок дії закону у часі із принципом правової визначеності видається очевидним.

Аналіз останніх досліджень та публікацій. У теорії права прийнято виділяти три випадки дії нової норми, що хоч і мають відмінні назви, змістовно складають три випадки дії прийнятої норми у часі. Вони називаються простою, переживаючою і зворотною дією закону у часі (С. Алексєєв), негайною, ультраактивною та ретроактивною дією (Р. Дворкін). Зміст цих випадків охоплює наступні ситуації: новоприйнятий закон 1) поширює свою дію на правовідносини після набуття ним чинності; 2) діє після втрати ним чинності протягом певного визначеного часу; 3) має зворотну дію.

Мета. Метою цієї статті $є$ встановлення співвідношення між дією закону у часі, забороною ретроспективної дії закону і принципом правової визначеності.

Основні результати дослідження. За загальним правилом введення в дію нормативного акта не може передувати його прийняттю, оприлюдненню і опублікуванню. Згідно зі статтею 58 Конституції України закони та інші нормативно-правові акти не мають зворотної дії у часі, окрім випадків, коли вони пом'якшують або скасовують відповідальність особи. Ніхто не може відповідати за діяння, які на час їх вчинення не визнавалися законом як правопорушення. Незважаючи на те, що термін «зворотна дія» застосовується у Конституції України в процитованій ст. 58, існує ще і інша стаття, зокрема стаття 57, яка хоч і не містить відповідного словосполучення, однак стосується набрання чинності нормативним актом, тобто визначає умови введення його в дію. Встановлено, що закони та інші нормативно-правові акти, що визначають права і обов'язки громадян, мають бути доведені до відома населення у порядку, встановленому законом, а за недотрмання цієї умови вони визнаються нечинними. Таке положення Конституції пов'язує дію закону з проінформованістю населення стосовно його положень.

Стаття 57 Конституції України встановлює таку умову, дотримання якої можливе за перспективної дії закону, значно ускладнене при негайному введенні закону в дію і неможливе при ретроактивній дії закону в часі. Це положення, на нашу думку, також слід вважати нормою, що забезпечує перспективну дію закону в часі. На це звернув увагу у своєму рішенні № 3-рп/2001 від 5 квітня 2001 року Конституційний Суд України, зазначивши у п. 4 - «дія закону та іншого нормативного акта не може поширюватися на правовідносини, які виникли і закінчилися до набрання чинності цим законом або іншим нормативним актом». Сдиним винятком з принципу незворотності дії закону в часі $є$ випадок, за якого закони або інші нормативно-правові акти пом'якшують або скасовують відповідальність особи.

Саме через це твердження більшість наукових розробок в частині незворотності дії закону у часі стосується саме декриміналізації діянь, і цей виняток з загального правила заслужив значно більше наукової уваги, аніж саме правило. В той час як узагальнюючий підхід до питання дії закону у часі виявляє його тісний зв'язок з іншими правовими принципами, зокрема 3 правовою визначеністю. Історичні витоки зародження і розвитку поглядів стосовно недопустимості зворотної дії закону у часі свідчать на користь такого підходу. У своєму дослідженні Р. Бабанли зазначає: «як показав 
аналіз джерел римського права положення про дію закону в часі у період їх зародження та початкового оформлення в законодавчі норми були тісно пов'язані з наявністю презумпції знання закону обвинуваченим». Досліджуючи розвиток положення про недопустимість зворотної дії закону, починаючи з Конституції Феодосія, автор стверджує, що заборона ретроактивної дії кримінального закону була згодом розширена до загального положення про заборону зворотної дії закону як такого. Заслуговує на увагу висновок автора про те, що підходи до темпоральної дії законів з римських часів «застосовувались на практиці і надалі аж до періоду розмежування гілок влади та обгрунтування відповідних концепцій» [2, с. 234]. 3 точки зору зв'язку правової визначеності і недопустимості зворотної дії закону в часі як ії елемента, момент для переосмислення цього вчення обраний невипадково. У історичному контексті, який пов’язаний з відстоюванням прав людини і боротьбою за них, були обрані і, з філософських позицій, обгрунтовані положення, які виступають до сьогодні юридичними гарантіями забезпечення прав людини. Невипадково у згаданому вище рішенні Конституційного Суду України № 3-рп/2001 від 5 квітня 2001 року зазначається, що «закріплення принципу незворотності дії у часі законів та інших нормативно-правових актів є гарантією безпеки людини і громадянина, довіри до держави». Такий зв’язок складових проявляється у принципі правової визначеності.

Правова визначеність у роботах українських вчених розглядається як визначеність правової системи, а не абсолютна визначеність правової норми [4, с. 56-57]. Ця визначеність складається з ряду аспектів, які узагальнюються у три групи.

На думку С. Погребняка, серед вимог правової визначеності можна виділити три групи: 1) вимоги до змісту норм права (зрозумілість, несуперечливість, доступність, повнота регулювання правових норм, відсутність широких дискреційних повноважень органів державної влади); 2) процедурні вимоги до нормативних актів; 3) вимоги до застосування нормативно-правових актів [5]. Елементи цього принципу взаємно доповнюють один одного. У межах принципу правової визначеності органічно проявляється взаємозв'язок дії закону у часі з теорією поділу влад, незалежністю гілок влади, створенням системи відповідальності держави за дотримання прав і свобод людини. Ці вимоги об'єднані у концепцію правової визначеності недарма. За твердженням науковців в основоположних правових джерелах, що закріплюють права і свободи людини - у Французькій Декларації прав людини, Французькій Конституції, Німецькому Кримінальному кодексі положення про недопустимість зворотної дії закону у часі зазначається як невід’ємна умова забезпечення прав і свобод людини [2, с. 234].

На підтримку такої думки виступає Р. Абрамович. Аналізуючи існуючі позиції щодо актуальності принципу незворотності дії закону в часі на прикладі Конституції США (1787 р.), Загальної Декларації прав людини (1948 р.) та інших документів, автор доходить висновку про закріплення у цих документах принципу незворотності дії закону у часі як такої , що має місце не тільки у разі пом’якшення і скасування ними відповідальності особи, а й допускається також у випадках, коли ці акти спрямовані на поліпшення правового становища фізичних і юридичних осіб». Натомість в Україні, стверджує автор, «конституційне формулювання цього принципу в ст. 58 є надто категоричним, що призвело до буквального його тлумачення Конституційним Судом України» [1, с. 61-62]. Дійсно, з положення ст. 58 Конституції України вбачається недопустимість зворотної дії закону, хоча теорія, узагальнюючи всі випадки введення в дію нормативного акта стверджує, що зворотна дія все ж зустрічається на практиці і має навіть свою самостійну назву - ретроспективна дія закону.

Як зазначалось вище, питання про зворотну дію закону в часі прийнято розглядати виключно крізь призму наявності або відсутності погіршення стану особи, що існував до моменту зміни, що викликано положенням ст. 58 КУ, яка саме в такому зв'язку розглядає поняття зворотної дії закону у часі. Натомість такий підхід $є$ дещо звуженим, застосовується в галузевому праві і не враховує всіх аспектів, які є важливими у випадку відходу від загальноприйнятого положення про дію закону у часі після його прийняття і оприлюднення. Питання дії закону у часі розглядається тільки крізь призму його регуляторної дії. «У державі, де діє принцип верховенства права проблеми, що охоплюють ретроактивну дію законів, є центральними. Виходячи з правової визначеності для громадян і юридичних осіб, важливо отримати доступ до правового регулювання та правових наслідків запланованих ними до вчинення дій перед тим, як приступити до їх втілення» [3, с. 43].

Однак, як вважає В. Попович, дія права хоч і має чітко виражений регуляторний вплив, що забезпечується примусовою дією правових норм, поряд з цим ще здійснює вплив на суспільні від- 
носини у інформаційний та ціннісно-орієнтаційний спосіб, інформуючи учасників правовідносин про правові норми та спрямовуючи відповідним чином їх діяльність [6, с. 228]. Ціннісно-орієнтаційний та інформаційний впливи можуть мати місце тільки тоді, коли здійснюється введення в дію закону в звичайний спосіб, закон поширює свою дію на майбутнє.

Кількість зверненнь до Конституційного Суду з різних галузевих питань стосовно тлумачення положення щодо зворотної дії закону в часі наштовхує на висновок, що відхід від традиційного порядку введення в дію правових актів створює необхідність у роз'ясненні правових питань через неможливість суб' єктів самостійно, без правового тлумачення, розібратись із тим, яке положення слід застосовувати і в який спосіб. У тих сферах, де правовідносини є численними і безперервними, у момент вступу закону в силу відбувається поділ правовідносин на два етапи не тільки за хронологічною ознакою, а й за ознакою різного правового впливу, адже правовідносини тривають, а норми права змінюються. Коли зміна нормативного акта впливає на значне коло триваючих правовідносин, суб'єкти перебувають у ситуації невизначеності, зміни тих істотних умов, що існували на момент їх вступу у правовідносини. Така ситуація ускладнюється ще і тим, що зміна балансу у правовому становищі суб'єктів призводить до того, що одна сторона внаслідок прийняття нормативного акта опиняється у більш вигідному положенні, ніж інша, і вправі ставити питання про збереження свого існуючого стану. Прикладом такої ситуації можна назвати проаналізовану І. Ющенком дію закону про Державний бюджет у часі. Автор стверджує, що «причина колізій дії у часі законів про Державний бюджет в тому, що не всі відносини, на врегулювання яких вони спрямовуються, можна одразу перелаштувати на новий лад, зважаючи на існуючі економічні, політичні, соціальні та інші обставини» [8, с. 108]. Шкода такими діями наноситься в першу чергу інформаційній та ціннісно-орієнтаційній дії правових норм, адже із зміною законодавства відбувається і зміна ціннісних орієнтирів, які, навіть за умови їх належного оприлюднення, суспільству належить усвідомити і прийняти. Постає питання: чому за абсолютної згоди стосовно того, що введення правових норм у ретроспективний спосіб становить загрозу дотриманню прав і свобод людини, практика таких дій існує, а її приклади до сих пір трапляються навіть у країнах розвиненої демократії. Очевидно це пов'язано з нагальною потребою змінити правове регулювання, у якому наявні недоліки. Однак зворотна дія закону у часі також може бути використана як спосіб політичного впливу. Книга «Правова роль судів у країнах сучасної демократії» розпочинається з твердження, що як і їх доіндустріальні противники, модерні демократії вважають суди незамінними політичними інституціями, тим самим підкреслюючи зв'язок політичних рішень і права $[9$, с. 1]. Адже виборчий процес у демократичних країнах веде до обрання представників певної політичної сили, які беруть у свої руки владу, а тому і використовують правові засоби для втілення своєї політичної програми. Концепція правової держави і дія принципу верховенства права передбачає, що такий вплив буде здійснюватись у правовий спосіб і єдиним способом здійснення втручання в права і свободи громадян $\epsilon$ правовий вплив. Тому, хоч теоретики права, зокрема, представники радянської школи позитивізму $\mathcal{C}$. Назаренко, П. Недбайло тощо та поодинокі прихильники природно-правового підходу того часу - С. Алексєєв та М. Козюбра; теоретики права за часів незалежної України - В. Копєйчиков, Н. Оніщенко тощо, стверджують, що правові норми мають діяти у перспективний спосіб (після їх прийняття і оприлюднення або на майбутнє) і лише в окремих випадках допускають можливість негайного введення в дію прийнятих нормативних актів та визнають можливість їх зворотної дії як виняток. Але під впливом політичних і суспільних процесів виникають спроби використати правове регулювання як зручний інструмент впливу, порушивши межі державного втручання у права і свободи громадян. «Особливо важливим цеє у випадку запровадження нових штрафів, податків або інших обов'язкових платежів, встановлення заборон на ті дії, вчинення яких було законним на момент прийняття нового акта» [3, с. 43]. Яскравим прикладом, який хотілося б навести для ілюстрації цього твердження, $є$ прийняття у 2009 році Закону України «Про заборону грального бізнесу в Україні». Відповідно до п. 2 прикінцевих положень цього закону - з дня набрання чинності цим законом видача ліцензій на провадження діяльності з організації та проведення азартних ігор в Україні припиняється, а ліцензії, видані суб'єктам підприємницької діяльності до набрання чинності цим законом, скасовуються. Це положення не вступає в конфлікт з нормами щодо перспективної дії закону, адже відносини регулюються «на майбутнє», разом з тим воно передбачає припинення дії ліцензій, які були видані суб'єктам господарювання строком на кілька років і були діючими на момент прийняття відповідних змін. Такі документи хоч і $є$ індивідуальними актами, 
однак їх видача грунтувалась на положенні про законність такої діяльності, суб'єкти господарювання організували такий вид діяльності - брали кредити, наймали працівників, орендували приміщення, вкладали кошти у відповідне обладнання, сплачували в дохід бюджету платежі за право вести таку діяльність. Звісно, рішення щодо заборони грального бізнесу виходило із ціннісних, а не економічних показників, в першу чергу, однак таке рішення забрало у підприємців, навіть тих, хто вже мав відповідні ліцензії, дія яких мала закінчитись далеко після прийняття вказаного закону, можливість здійснювати таку діяльність. Спираючись на цей приклад, $є$ всі ознаки стверджувати, що законні очікування особи, які вона мала у зв'язку з прийняттям цього закону, суттєво змінилися. Наведений приклад ілюструє, наскільки суттєвими можуть бути наслідки зміни законодавства, і наскільки детальною має бути законодавча регламентація перехідного періоду, особливо у тих сферах, де дія закону поширюється на відносини, що виникли до його прийняття і триватимуть у майбутньому.

Висновки. За загальним правилом прийняття і введення в дію нормативних актів, їх дія поширюється у перспективний спосіб, вони вводяться в дію для регулювання відносин на майбутнє. Окрім регуляторного впливу, спираючись на таку процедуру, суб'єкт має можливість усвідомити зміст правового припису, сформувати свої правові погляди, він стає проінформованим про наслідки своїх дій, в першу чергу, правові. Такий порядок $є$ певною гарантією для фізичних і юридичних осіб у взаємовідносинах з державою, захистом від свавільного втручання у здійснення своїх прав. Недопустимість зворотної дії закону є невід'ємною складовою принципу правової визначеності і нерозривно пов'язується з іншими його елементами.

\section{Список використаних джерел}

1. Абрамович Р. М. Принцип незворотності дії закону в часі у рішеннях Конституційного Суду України // Держава і право : зб. наукових праць. Юридичні і політичні науки. Випуск 54. - К. : Інститут держави і права ім. В. М. Корецького НАН України, 2010. - С. 61-67.

2. Бабанли Р. Ш. Історичний розвиток положень про заборону зворотної дії кримінального закону в часі //Часопис Київського університету права. - 2014. - № 4. - С. 233-237.

3. Bernitz U. Retroactive Legislation in a European Perspective - on the Importance of General Principle of Law. [Електронний ресурс]. - Режим доступу : http://www.scandinavianlaw.se/pdf/39-3.pdf

4. Принции верховенства права у діяльності держави та в адміністративному праві / ред. Ю. С. Шемшученка. К. : Конус-Ю, 2008. - С. 314.

5. Погребняк С. Принцип правової визначеності як загальний принцип права / Антропологія права: філософський та юридичний виміри (стан, проблеми, перспективи). Матеріали учасників Міжнародного круглого столу 3-5 грудня 2010 р. - Львів : Галицький друкар, 2010. - С. 490-507.

6. Попович B. М. Теорія держави і права: концепція, праксеологія та методологія розвитку : моногр. - К. : Юрінком Інтер, 2015. - 384 c.

7. Рішення Конституційного Суду України у справі за конституційним поданням Президента України щодо відповідності Конституції України (конституційності) Закону України «Про внесення змін до деяких законодавчих актів України» (справа про податки) №1-16 /2001 від 5 квітня 2001 року [Електронний ресурс]. - Режим доступу : https://zakon.rada.gov.ua/laws/show/v003p710-01

8. Ющенко I. Дія закону про Державний бюджет (теоретичні аспекти) // Вісник Київського національного університету імені Тараса Шевченка. Серія : Юридичні науки, 2011. - № 87. - С. 106-109.

9. Waltman J., Holland K. The Political Role of Law Courts in Modern Democracies Palgrave Macmillan, USA. 1988. 236 p.

\section{References}

1. Abramovych R. M. Pryntsyp nezvorotnosti dii zakonu v chasi u rishenniakh Konstytutsiinoho Sudu Ukrainy // Derzhava i pravo: Zb. naukovykh prats. Yurydychni i politychni nauky. Vypusk 54. - K. : Instytut derzhavy i prava im. V. M. Koretskoho NAN Ukrainy, 2010. - S. 61-67.

2. Babanly R. Sh. Istorychnyi rozvytok polozhen pro zaboronu zvorotnoi dii kryminalnoho zakonu v chasi //Chasopys Kyivskoho universytetu prava. - 2014. - № 4. - S. 233-237.

3. Bernitz U. Retroactive Legislation in a European Perspective - on the Importance of General Principle of Law [Електронний ресурс]. - Режим доступу : http://www.scandinavianlaw.se/pdf/39-3.pdf

4. Pryntsyp verkhovenstva prava u diialnosti derzhavy ta v administratyvnomu pravi / red. Yu. S. Shemshuchenka. - K. : Konus-Yu, 2008. - S. 314. 
5. Pohrebniak S. Pryntsyp pravovoi vyznachenosti yak zahalnyi pryntsyp prava / Antropolohiia prava: filosofskyi ta yurydychnyi vymiry (stan, problemy, perspektyvy). Materialy uchasnykiv Mizhnarodnoho kruhloho stolu 3-5 hrudnia 2010 r. Lviv : Halytskyi drukar, 2010. - S. 490-507.

6. Popovych V. M. Teoriia derzhavy i prava: kontseptsiia, prakseolohiia ta metodolohiia rozvytku: Monohrafiia. - Kyiv: Yurinkom Inter, 2015. - 384 s.

7. Rishennia Konstytutsiinoho Sudu Ukrainy u spravi za konstytutsiinym podanniam Prezydenta Ukrainy shchodo vidpovidnosti Konstytutsii Ukrainy (konstytutsiinosti) Zakonu Ukrainy «Pro vnesennia zmin do deiakykh zakonodavchykh aktiv Ukrainy» (sprava pro podatky) №1-16 /2001 vid 5 kvitnia 2001 Elektronnyi resurs. - Rezhym dostupu : https://zakon.rada.gov.ua/laws/show/v003p710-01

8. Iushchenko I. Diia zakonu pro Derzhavnyi biudzhet (teoretychni aspekty) / Visnyk Kyivskoho natsionalnoho universytetu imeni Tarasa Shevchenka. Seriia : Yurydychni nauky, 2011. - № 87. - S. 106-109.

9. Waltman J., Holland K. The Political Role of Law Courts in Modern Democracies Palgrave Macmillan, USA. 1988. 236 p.

\section{Огнев'юк Г. 3. Дія закону у часі як вимога правової визначеності}

Стаття присвячена комплексному розгляду питання про дію закону у часі та його зв'язку з принципом правової визначеності. 3 набуттям чинності нової норми правовідносини, що виникають після її введення в дію, регулюватимуться в новий спосіб, триваючі на момент прийняття правовідносини адаптуються до нового правила, створюючи загрозу визначеності правового становища та існуючих критеріїв правомірної поведінки. Вказівником у такій ситуації для учасників правовідносин можуть слугувати перехідні положення нормативних актів, що визначають, який саме законодавчий акт слід застосувати до відносин, що тривають і підпадають під дію новоствореного закону. Однак перехідні положення не є обов'язковим елементом правового акта, тому їх включення у закон залишається на розсуд законодавця. У статті проаналізовано випадки ретроспективної дії закону та вказано, що навіть за умови покращення правового становища осіб внаслідок зворотної дії закону, такі дії створюють загрозу порушенню принципу правової визначеності.

Ключові слова: ретроспективна дія закону, правова визначеність, верховенство права, принципи права, законні очікування.

\section{Ogneviuk G. Z. Act of time as a requirement of legal certainty}

The article is devoted to the complex consideration of the question of the effect of the law in time and its relation to the principle of legal certainty. With the coming into force of the new norm, the legal relationship that was not finished by the time should be adopted to the new rules, which sometimes are quite different from the law, regulating them previously. New criteria of legal and illegal arises for the parts of the relations, and the relations themselves transform. Any significant changes of such kind provoke a situation of uncertainty and attack stability and predictability of law. Due to the evolution of social relations and legal norms the law can't be absolutely constant. The majority of its changes are necessary and obvious, they correspond to the needs of society. When the law is enforced for the future - legal certainty and predictability are not injured. But when it is enforced in a retrospective way there is a violation of legal certainty principle. A number of scientific positions on this point pay attention to the fact, that retrospective act of law is possible only when it improves the rights, gives new legal preferences to the person. But even than, we should recognize that legal norm acts on a number of relations, so in the case it is not the individual act, as a court decision, for example, the way it influences the relations is not entirely predictable. It becomes evident in certain situations that individuals would prefer to avoid participation in such relations as far as they know about the new rules. As a result, it is stated that retroactive way to enforce law doesn't correspond to the legal certainty principle. And when law is enforced the legal certainty principle as a general law principle should be regarded.

Key words: retroactive law, legal certainty, rule of law, law principles, legitimate expectations.

DOI: 10.33.66.3/2524-017X-2019-10-213-217 